\title{
Annatto seed by-product in diets containing sorghum for commercial laying hens ${ }^{1}$
}

\author{
Resíduo da semente do urucum em dietas contendo sorgo para poedeiras comerciais
}

\author{
Marcelle Craveiro Abreu de Melo ${ }^{2 *}$, Ednardo Rodrigues Freitas ${ }^{2}$, Francisco Diego Teixeira Dantas ${ }^{2}$, Danilo \\ Rodrigues Fernandes ${ }^{2}$ and Pedro Henrique Watanabe ${ }^{2}$
}

\begin{abstract}
The aim of this study was to evaluate the effect of including annatto seed by-product (ASB) in diets containing sorghum on nutrient utilization, performance and characteristics of the eggs of laying hens. A total of 288 Lohman Brown laying hens, 34 weeks of age, were distributed in completely randomized design with six treatments and six replications of the eight birds each other. The treatments consisted of a diet with corn as an energy source and other with sorghum and inclusion of $0,25,45,65$ and $85 \mathrm{~g} / \mathrm{kg}$ of ASB. Comparing the results, increasing levels of RSU did not affect the metabolizability of nutrients, and utilization the energy of the feed. It was also observed there was no effect on the performance and parameters egg quality, except for yolk color. There was a significant linear increase in yolk colour with inclusion of ASB. We concluded that the annatto seed by-product can be used at levels up to $85 \mathrm{~g} / \mathrm{kg}$ in laying hen diets containing sorghum as the main source of energy, with the possibility of reducing yolk pigmentation problems, caused by the total substitution of corn by sorghum, with the inclusion of ASB from $25 \mathrm{~g} / \mathrm{kg}$.
\end{abstract}

Key words: Alternative feedstuff. Bixa orellana L. Bixin. Carotenoids. Yolk colour.

\begin{abstract}
RESUMO - Objetivou-se avaliar o efeito da inclusão do resíduo da semente de urucum (RSU) em dietas contendo sorgo sobre o aproveitamento dos nutrientes, o desempenho e as características dos ovos de galinhas poedeiras. Um total de 288 galinhas poedeiras Lohman Brown, 34 semanas de idade, foram distribuídas em delineamento inteiramente casualizado, com seis tratamentos e seis repetições das oito aves. Os tratamentos consistiram de uma dieta com milho como fonte de energia e as demais com sorgo e inclusão de 0, 25, 45, 65 e $85 \mathrm{~g} / \mathrm{kg}$ de RSU. Comparando os resultados, o aumento dos níveis de RSU não afetou a metabolizabilidade dos nutrientes e a utilização da energia da ração. Também foi observado que não houve efeito no desempenho e nos parâmetros da qualidade dos ovos, exceto na cor da gema. Houve aumento linear significativo na cor da gema com a inclusão do RSU. Concluímos que o resíduo da semente de urucum pode ser utilizado em níveis de até $85 \mathrm{~g} / \mathrm{kg}$ em dietas para galinhas poedeiras contendo sorgo como principal fonte de energia, com a possibilidade de reduzir problemas de pigmentação da gema, causados pela substituição total de milho por sorgo, com a inclusão de RSU de $25 \mathrm{~g} / \mathrm{kg}$.
\end{abstract}

Palavras-chave: Alimento alternativo. Bixa orellana L. Bixina. Carotenoides. Cor da gema.

DOI: $10.5935 / 1806-6690.20210047$

Editor-in-Chief: Profa. Andrea Pereira Pinto - deiapp@hotmail.com

*Author for correspondence

Received for publication 17/06/2020; approved on 30/11/2020

'Parte da dissertação de mestrado do terceiro autor, apresentada na Universidade Federal do Ceará/UFC

2DDepartamento de Zootecnia, Centro de Ciências Agrárias/CCA, Universidade Federal do Ceará/UFC, Fortaleza-CE, Brasil, marcellecraveiro@hotmail.com (ORCID ID 0000-0001-7345-5995), ednardo@ufc.br (ORCID ID 0000-0001-7226-9517), diegoteixeira@zootecnista.com.br (ORCID ID 0000-0002-3627-6960), danilo_zoo@hotmail.com (ORCID ID 0000-0001-9801-8273), pedrowatanabe@ufc.br (ORCID ID0000-0002-1010-2305) 


\section{INTRODUCTION}

The sorghum, increasingly, have been used in poultry feed formulations as an alternative ingredient to corn. Research results show the possibility of replacing up to $100 \%$ of corn by sorghum without causing damages on poultries performance (FAGUNDES et al., 2017; MORAES et al., 2016; SALEH et al., 2019). However, the use of sorghum causes a decrease in pigmentation of the meat and egg yolk of the birds (MOURA et al., 2010; SOUZA et al., 2015; SOUZA et al., 2019).

To solve the pigmentation problems of poultry products associated with the use of sorghum in the diets, the inclusion of a source of pigments in the feed is necessary (KUFEL et al., 2019). The natural pigments are the most studied currently due to the trend toward use of these products in the human and animal feed, because, as well as improving a product's colour, the use of natural additives (i.e., carotenoids) should also provide stability, safety and to be commercially applicable (UL-ISLAM; RATHER; MOHAMMAD, 2015). In this context, the annatto seeds (Bixa orellana L.) stands out as an excellent source of pigments, since the major part of the seeds are comprised of the colorants bixin and norbixin (BOLOGNESI; GARCIA, 2018).

The largest producers of annatto are the Latin American countries, followed by African and Asian countries (RADDATZ-MOTA et al., 2017). To obtain the products of the annatto for food industry, much of the seed is not used after the processing, making it a waste that can come to pollute the environment (SILVA et al., 2006). However, chemical composition analysis of this residue (SOUZA et al., 2015) indicate the possibility of its use in the poultry feed. In addition to the nutritional value, the red colour of this residue also indicates the presence of pigments, which may contribute to the pigmentation of the poultry products.

Therefore, the objective was to evaluate the effect of the inclusion of ASB in diets of laying hens containing sorghum as the main source of energy, through its effects on nutrient utilization, poultry performance and egg characteristics, in order to determine the best level of inclusion of this feed ingredient in diets.

\section{MATERIAL AND METHODS}

The experiment was conducted at the poultry section at the Department of Animal Science, at the Agrarian Science Center of the Federal University of Ceará.

The annatto seed by-product was obtained from the extraction of natural pigments present in the seed pulp and purchased from a fruit processing company for use in the food industry. The process of extracting these pigments was done by centrifuging in water, and the by-product from this extraction was dried and ground for later use in the poultry diet. The ASB obtained was a red color, indicating the presence of pigments.

For the experiment, a total of 288 Lohmann Brown laying hens, 34 weeks old, were housed based on average weight and the eggs production, in galvanized wire cages $(25 \times 40 \times 30 \mathrm{~cm})$ with a density of two hens per cage. Each cage had a nipple drinker and a trough-type feeder at the front of the cage. All the procedure described herein were approved by Animal Research Ethics Committee Federal University of Ceará (protocol no 21/2013).

The laying hens were distributed in a completely randomized design with six treatments and six replicates of eight birds each. Treatments consisted of a control diet based on corn as the main energy ingredient, and the others five treatments contained sorghum instead of corn, with the inclusion of ASB in proportions of $0,25,45,65$ and $85 \mathrm{~g} / \mathrm{kg}$.

The experimental diets (Table 1) were formulated to be isoenergetic and isonutritive, considering the nutritional recommendations proposed in National Research Council (1994) for laying hens. The bromatologic composition values of the annatto seed by-product were also considered, according Souza et al. (2015), which contained $88.77 \%$ dry matter, $2.813 \mathrm{kcal} / \mathrm{kg}$ of metabolizable energy corrected for the nitrogen balance, $13.46 \%$ crude protein, $12.81 \%$ acid detergent fiber, $32.94 \%$ neutral detergent fiber, $1.65 \%$ ether extract, $3.14 \%$ mineral matter, $0.18 \%$ calcium, $0.31 \%$ phosphorus, $0.61 \%$ total lysine, $0.21 \%$ total methionine, $0.38 \%$ total methionine + cystine, $0.09 \%$ total tryptophan, and $0.41 \%$ total threonine (values expressed in the fresh matter).

The experimental period constituted four periods of 21 days, and all birds received food diet and water ad libitum. The lighting program during the experiment was 16 hours of light (natural + artificial) daily. The average minimum and maximum temperature and relative humidity in the shed during the experimental period were $27.11^{\circ} \mathrm{C}, 30.43{ }^{\circ} \mathrm{C}$ and $67.31 \%$, respectively.

The following performance variables were evaluated: feed intake (g/bird/day), egg production (\%/bird/day), egg weight (g), produced egg mass ( $\mathrm{g} /$ bird/day), feed conversion (feed intake/egg mass).

At the beginning and end of each period, the rations provided and the leftovers were weighed to determine feed intake. The egg production was recorded daily by cage and at the end of each period, the percentages of posture per repetition were calculated.

The mean weight of the egg was obtained by dividing the total weight of the eggs collected by the number of eggs laid per replicate in each period. From the number of eggs and the average weight of the egg, the egg 
mass per repetition and per period was calculated. The feed conversion for each repetition, per period, was calculated from the relationship between feed intake and produced egg mass. The performance data were corrected for mortality.

To evaluate the effects of the level of ASB in diets containing sorghum on the metabolization of nutrients, a trial was performed using the total excreta collection method (SIBBALD; SLINGER, 1963) carried out on the first four days of the third experimental period.

The excreta were collected twice a day ( 8 a.m. and 4 p.m.) into trays covered with plastic placed under each cage. After the collection period, the samples were properly identified and forwarded to the laboratory for oven drying forced ventilation at $55^{\circ} \mathrm{C}$ for 72 hours. Diets and excreta samples were ground in a knife type grinder and analysed for dry matter (DM), nitrogen (N) and gross energy (GE), according to the methodology described the Association of Official Analytical Chemists (1995). The GE was determined using an adiabatic bomb calorimeter (PARR brand model 1241EA).

Based on the results the metabolizable coefficient (MC) of DM, N and GE was calculated. The apparent

Table 1 - Composition, and nutritional and energy contents of experimental diets (dry matter basis)

\begin{tabular}{|c|c|c|c|c|c|c|}
\hline \multirow{2}{*}{ Ingredients } & \multicolumn{6}{|c|}{ Treatments } \\
\hline & $\mathrm{T} 1$ & $\mathrm{~T} 2$ & $\mathrm{~T} 3$ & $\mathrm{~T} 4$ & $\mathrm{~T} 5$ & T6 \\
\hline Corn & 634.9 & 0.0 & 0.0 & 0.0 & 0.0 & 0.0 \\
\hline Sorghum & 0.0 & 630.0 & 607.0 & 588.4 & 570.0 & 551.5 \\
\hline Soybean meal & 241.7 & 226.9 & 224.0 & 221.7 & 219.4 & 217.0 \\
\hline Soybean oil & 12.3 & 31.8 & 32.9 & 33.8 & 34.7 & 35.6 \\
\hline Annatto seed by-product & 0.0 & 0.0 & 25.0 & 45.0 & 65.0 & 85.0 \\
\hline Calcitic Limestone & 87.2 & 87.6 & 87.7 & 87.8 & 87.9 & 88.0 \\
\hline Dicalcium phospate & 15.1 & 14.6 & 14.3 & 14.1 & 13.9 & 13.6 \\
\hline Mineral and vitamin supplement ${ }^{1}$ & 3.0 & 3.0 & 3.0 & 3.0 & 3.0 & 3.0 \\
\hline Salt & 4.6 & 4.6 & 4.6 & 4.6 & 4.6 & 4.7 \\
\hline DL-Methionine & 1.2 & 1.5 & 1.5 & 1.6 & 1.5 & 1.6 \\
\hline TOTAL (Kg) & 1000 & 1000 & 1000 & 1000 & 1000 & 1000 \\
\hline \multicolumn{7}{|l|}{ Nutritional level calculated } \\
\hline Metabolizable energy (MJ/kg) & 11.72 & 11.72 & 11.72 & 11.72 & 11.72 & 11.72 \\
\hline Crude Protein (g/kg) & 160.0 & 160.0 & 160.0 & 160.0 & 160.0 & 160.0 \\
\hline Dry matter (g/kg) & 889.0 & 893.9 & 893.8 & 893.7 & 893.6 & 893.6 \\
\hline Neutral detergent fibre $(\mathrm{g} / \mathrm{kg})$ & 95.8 & 83.3 & 90.1 & 95.7 & 101.2 & 106.7 \\
\hline Acid detergent fibre (g/kg) & 36.0 & 48.9 & 51.1 & 52.8 & 54.6 & 56.4 \\
\hline Calcium $(\mathrm{g} / \mathrm{kg})$ & 38.0 & 38.0 & 38.0 & 38.0 & 38.0 & 38.0 \\
\hline Available phosphorus (g/kg) & 3.7 & 3.7 & 3.7 & 3.7 & 3.7 & 3.7 \\
\hline Sodium (g/kg) & 2.0 & 2.0 & 2.0 & 2.0 & 2.0 & 2.0 \\
\hline Total Lysine (g/kg) & 8.2 & 7.6 & 7.6 & 7.6 & 7.6 & 7.7 \\
\hline Methionine + total cystine $(\mathrm{g} / \mathrm{kg})$ & 7.1 & 7.0 & 7.0 & 7.0 & 7.0 & 7.0 \\
\hline Total Methionine (g/kg) & 4.4 & 4.5 & 4.5 & 4.6 & 4.5 & 4.6 \\
\hline Total threonine $(\mathrm{g} / \mathrm{kg})$ & 6.3 & 5.9 & 5.9 & 5.8 & 5.8 & 5.8 \\
\hline Total tryptophan $(\mathrm{g} / \mathrm{kg})$ & 1.9 & 2.0 & 2.0 & 2.0 & 2.0 & 2.0 \\
\hline
\end{tabular}

${ }^{1} \mathrm{~T} 1=100 \%$ Corn $+0 \mathrm{~g} / \mathrm{kg}$ ASB; $\mathrm{T} 2=100 \%$ Sorghum $+0 \mathrm{~g} / \mathrm{kg} \mathrm{ASB} ; \mathrm{T} 3=100 \%$ Sorghum $+25 \mathrm{~g} / \mathrm{kg} \mathrm{ASB} ; \mathrm{T} 4=100 \%$ Sorghum $+45 \mathrm{~g} / \mathrm{kg}$ ASB; $5=100 \%$ Sorghum $+65 \mathrm{~g} / \mathrm{kg} \mathrm{ASB} ; \mathrm{T} 6=100 \%$ Sorghum $+85 \mathrm{~g} / \mathrm{kg} \mathrm{ASB} ;{ }^{2}$ Mineral e vitamin supplement (composition per kg of product): Pantothenic acid (min.) 2,580 mg; Zinc Bacitracin (min.) 6,750,00 mg; Copper (min.) $30.66 \mathrm{mg}$; Choline (min.) $60 \mathrm{mg}$; Ferrid (min.) $16.59 \mathrm{mg}$; Iodine (min.) $240 \mathrm{mg}$; Manganese (min.) $22.31 \mathrm{mg}$; Methionine (min.) $200 \mathrm{mg}$; Niacin (min.) 6,600 mg; Selenium (min.) $100 \mathrm{mg}$; Zinc (min.) $17.16 \mathrm{mg}$; Vitamin A (min.) 2,350,000 mg; Vitamin B1 (min.) $440 \mathrm{mg}$; Vitamin B2 (min.) $990 \mathrm{mg}$; Vitamin B6 (min.) $550 \mathrm{mg}$; Vitamin B12 (min.) 2,600 mg; Vitamin D3 (min.) 567,500 mg; Vitamin E (min.) 1,750 mg; Vitamin K3 (min.) $400 \mathrm{mg}$ 
metabolizable energy (AME) and AME corrected for nitrogen balance (AMEn) of the diets were calculated using the equations proposed by Matterson et al. (1965).

The following quality of eggs variables were evaluated: specific density (SD), Haugh units (HU), percentage of yolk, albumen and eggshell, thickness of eggshell (EC), yolk colour.

The evaluation of the quality of the eggs was made once a week during the experimental period. For this, the eggs of each replicate were collected and three of them were selected by the egg weight average of each replicate (avoiding broken, cracked or dirty eggs) to be used in the evaluation.

Initially, the specific density (SD) of eggs was determined, according to Freitas et al. (2004). After the determination of the $\mathrm{SD}$, the eggs were broken on a glass surface to determine the albumen height using a depth micrometer. The albumen height data and egg weight were used to calculate the value of Haugh units (HU), using the equation $\mathrm{HU}=100 \log (\mathrm{H}+\mathrm{W} 7.57-1.7 \mathrm{~W} 0.37)$, where $\mathrm{H}$ is the albumen height $(\mathrm{mm})$ and $\mathrm{W}$ egg weight $(\mathrm{g})$.

To determine the proportion (\%) of each constituent in the eggs, the egg yolks were separated and weighed on precision scales $(0.01 \mathrm{~g})$, and the eggshells were washed, dried at room temperature for 48 hours and then weighed. The proportions of eggshell and yolk were obtained from the ratio of the weight of each portion and egg weight and the proportion of the albumen. This was determined using the following equation: albumen $=100-($ egg yolk + eggshell $)$.

Yolk colour was analysed using the subjective method with the aid of the Roche color fan and the objective method using a digital Minolta Chroma Meter CR400 colorimeter, operating in the CIE system ( $\left.\mathrm{L}^{*}, \mathrm{a}^{*}, \mathrm{~b}^{*}\right)$, where $\mathrm{L}^{*}=$ brightness, $\mathrm{a}^{*}=$ the colour intensity from red to green, $\mathrm{b}^{*}=$ colour intensity from yellow to blue.

The subjective method was measured with the Roche color fan by an only observer during the experimental period. Egg yolks were evaluated under indirect natural lux, without hard artificial light, always on a non-reflective white surface. The Roche color fan was positioned immediately above the yolk and observed vertically.

A statistical analysis of the data was performed using the Statistical Analysis System, version 9.3 (SAS Institute Inc., Cary, NC). The data for the treatments with $25,45,65$ and $85 \mathrm{~g} / \mathrm{kg}$ of ASB were subjected to regression analysis, according to a completely randomized design, to determine the best level of inclusion of ASB in the diets. Then, the data from all treatments were compared using a SNK test at 5\% of significance.

\section{RESULTS AND DISCUSSION}

The metabolizable coefficients of nutrients and metabolizable energy values of diets are shown in Table 2 . There was no difference $(P>0.05)$ between treatments for AME, AMEn, MCDM, MCN and MCGE.

According to the results, the total replacement of corn by sorghum and the inclusion of up to $85 \mathrm{~g} / \mathrm{kg}$ of ASB in diets with sorghum as the main energy source had no significant influence on nutrition utilization in laying hen diets and, consequently, in the metabolizable energy values of the feed.

Whereas the experimental diets were formulated to be isoenergetic, based on the metabolizable energy values of the ASB determined by Souza et al. (2015), and for the other ingredients, indicated by National Research Council (1994), it was expected that the metabolizable energy of the ration did not vary between treatments. Values of metabolizable energy between the diets and in relation to the calculated value (Table 1) showed similarity between the composition of ingredients and the tabulated values (FREITAS et al., 2011).

In some reports in the literature (SILVA et al., 2005, 2006) researchers have indicated that the inclusion of annatto seed and by-products from the processing of annatto seed in animal diets proportionately increases the gross fibre. Consequently, due to this increase in gross fibre in the diet, there is a dilution of available energy and a reduction in the use of energy due to lower digestibility of nutrients.

Due to these characteristics, Arraya et al. (1977), recommends the inclusion a maximum of $100 \mathrm{~g} / \mathrm{kg}$ of the annatto seed in the diets of laying hens and $50 \mathrm{~g} / \mathrm{kg}$ of ASB in the diets for broilers (SILVA et al., 2005). However, although there was an increase in fibre content of the diets when the level of ASB was increased, this increase was not enough to promote differences $(\mathrm{P}>0.05)$ in digestibility and metabolizable energy in the diet.

For the performance data shown in Table 3, the total replacement of corn by sorghum and the inclusion of ASB in diets containing sorghum did not affect $(P>0.05)$ the performance variables.

Evaluating the inclusion of ASB in the diets for laying hens, Silva et al. (2006), reported that from $40 \mathrm{~g} / \mathrm{kg}$ of inclusion of ASB for laying hens there was an increase in feed intake by poultry occurred to compensate for the reduced availability of energy for metabolic and production processes, caused by increases of fibre contained in the diet. In this context, it can be inferred that the absence of a significant effect of the inclusion of ASB on feed intake, detected in this study, can be attributed a lack of change in energy metabolism, demonstrating that the broilers were able to meet their requirements. 
The intake of energy and protein for laying hens are factors that can affect egg production (MOLNÁR et al., 2018). In turn, egg weight can be influenced by the intake of protein and amino acids, especially lysine and methionine
(BRAZ et al., 2007). Thus, to avoid problems, it is essential to ensure the daily feed intake by poultry in an attempt to meet the demand for energy and nutrients in the birds. Based on the above, given that the feed intake did not vary

Table 2 - Metabolizable coefficients and metabolzable energy values of diets for laying hens containing sorghum and different levels of annatto seed by-product

\begin{tabular}{|c|c|c|c|c|c|c|}
\hline \multirow{2}{*}{ Treatments } & \multicolumn{6}{|c|}{ Parameters $^{1}$} \\
\hline & $\mathrm{AME}(\mathrm{MJ} / \mathrm{kgDM})$ & $\operatorname{AMEn}(\mathrm{MJ} / \mathrm{kgDM})$ & AMEn (MJ/kgNM) & MCDM & MCGE & $\mathrm{MCN}$ \\
\hline Corn $+0 \mathrm{~g} / \mathrm{kg} \mathrm{ASB}{ }^{2}$ & 13.64 & 13.33 & 11.77 & 0.736 & 0.790 & 0.402 \\
\hline Sorghum $+0 \mathrm{~g} / \mathrm{kg}$ ASB & 13.58 & 13.40 & 12.03 & 0.716 & 0.783 & 0.400 \\
\hline Sorghum $+25 \mathrm{~g} / \mathrm{kg} \mathrm{ASB}$ & 13.25 & 12.92 & 11.67 & 0.726 & 0.769 & 0.409 \\
\hline Sorghum $+45 \mathrm{~g} / \mathrm{kg} \mathrm{ASB}$ & 13.11 & 12.93 & 11.70 & 0.731 & 0.774 & 0.374 \\
\hline Sorghum $+65 \mathrm{~g} / \mathrm{kg}$ ASB & 13.32 & 13.03 & 11.60 & 0.715 & 0.767 & 0.390 \\
\hline Sorghum $+85 \mathrm{~g} / \mathrm{kg}$ ASB & 13.28 & 13.05 & 11.76 & 0.708 & 0.761 & 0.376 \\
\hline Average & 13.34 & 13.10 & 11.76 & 0.721 & 0.773 & 0.392 \\
\hline $\mathrm{ANOVA}^{3}$ & \multicolumn{6}{|c|}{$P$-value } \\
\hline Treatments & 0.2355 & 0.1244 & 0.2511 & 0.5272 & 0.3373 & 0.8067 \\
\hline Regression Analysis & \multicolumn{6}{|c|}{$P$-value } \\
\hline Linear & 0.8992 & 0.4496 & 0.7934 & 0.1819 & 0.4801 & 0.3675 \\
\hline Quadratic & 0.9599 & 0.9807 & 0.6343 & 0.6635 & 0.5771 & 0.7356 \\
\hline SEM $^{4}$ & 2.87 & 2.62 & 2.62 & 3.62 & 2.89 & 12.20 \\
\hline
\end{tabular}

${ }^{1}$ AME - Apparent Metabolizable Energy, AMEn - Apparent Metabolizable Energy corrected for nitrogen balance, DM - Dry Matter, NM - Natural Matter, MCDM - Metabolizable Coefficient of Dry Matter, MCGE - Metabolizable Coefficient of Gross Energy, MCN - Metabolizable Coefficient of nitrogen; ${ }^{2}$ ASB-Annatto Seed by-product; ${ }^{3}$ ANOVA - Analysis of variance $(P>0.05)$ Statistically effect not significant; ${ }^{4} \mathrm{SEM}$ - Standard error of the mean

Table 3 - Performance of laying hens fed with diets containing sorghum and annatto seed by-product

\begin{tabular}{lccccc}
\hline Treatments & \multicolumn{5}{c}{ Parameters $^{1}$} \\
\cline { 2 - 5 } & FI (g/poultry) & EW $(\mathrm{g})$ & EP $(\%)$ & EM (g/poultry/day) & FC $(\mathrm{g} / \mathrm{g})$ \\
\hline Corn + 0 g/kg ASB ${ }^{2}$ & 104.85 & 60.37 & 93.95 & 56.72 & 1.85 \\
Sorghum + 0 g/kg ASB & 109.80 & 60.55 & 94.18 & 57.03 & 1.93 \\
Sorghum + 25 g/kg ASB & 104.91 & 60.91 & 92.62 & 56.41 & 1.86 \\
Sorghum + 45 g/kg ASB & 106.60 & 60.53 & 93.41 & 56.55 & 1.89 \\
Sorghum + 65 g/kg ASB & 106.85 & 61.16 & 91.49 & 55.96 & 1.91 \\
Sorghum + 85 g/kg ASB & 109.42 & 60.27 & 94.45 & 56.93 & 1.92 \\
\hline Average & 107.27 & 60.64 & 93.34 & 56.60 & 1.89 \\
\hline ANOVA & & & & \\
\hline Treatment & 0.4918 & 0.8785 & 0.7338 & 0.9844 & 0.4934 \\
\hline Regression Analysis & & & $P$-value & & 0.2064 \\
\hline Linear & 0.2102 & 0.6381 & 0.6205 & 0.8467 & 0.8505 \\
\hline Quadratic & 0.8453 & 0.6618 & 0.4973 & 0.7104 & 3.93 \\
\hline SEM $^{4}$ & 4.82 & 2.24 & 3.87 & 4.65 & \\
\hline
\end{tabular}

${ }^{1} \mathrm{FI}$ - Feed Intake; EW - Egg Weight; EP - Egg Production; EM - Egg Mass; FC - Feed Conversion; ${ }^{2} \mathrm{ASB}$ - Annatto seed by-product; ${ }^{3} \mathrm{ANOVA}$ - Analysis of variance $(P>0.05)$ Statistically effect not significant; ${ }^{4} \mathrm{SEM}$ - Standard error of the mean 
between poultry submitted to different treatments, it can be inferred that the nutritional demand of laying hens was met, thus justifying the absence of significant differences in egg production, weight and egg mass between poultry submitted to different treatments.

The effects of replacing corn by sorghum and the inclusion of ASB on poultry performance observed in this study are similar to those reported by Braz et al. (2007), Garcia et al. (2009, 2010) Garcia et al. (2015) and Laganá et al. (2011), also reported similar performance of laying hens with inclusion of annatto seed in the diet. However, Silva et al. (2006) found that the increase in inclusion of ASB from 40 to $120 \mathrm{~g} / \mathrm{kg}$ in laying hen diets containing $40 \%$ sorghum, caused a linear increase in feed intake in egg laying and egg mass percentage. Moreover, the feed conversion per kilogram of eggs and per dozen eggs improved linearly.

For variables of egg quality (Table 4), there was no significant effect of treatments. According to the results, the total replacement of corn by sorghum or the inclusion of ASB where sorghum is the main source of energy, in isonutrient diets, there was no influence on the proportion of constituents of eggs, in the albumen quality measured by Haugh units or eggshell quality measured by the specific density or thickness of the eggshell.

The absence of a significant influence on eggs characteristics due to the total replacement of corn by sorghum and the inclusion of ASB was also reported by Braz et al. (2007). In turn, Garcia et al. (2010), Garcia et al. (2015), Laganá et al. (2011) and Spada et al. (2012) and included annatto seed at different levels in laying hen diets, with variations from 25 to $50 \mathrm{~g} / \mathrm{kg}$, and found no significant differences in specific gravity, yolk height, Haugh units, yolk weight, weight and thickness of eggshell.

There were significant differences between treatments for all variables of yolk colour measured by the colorimetric range and digital colorimeter (Table 5).

Evaluating the yolk colour by colour range, there was a reduction in colour with the total replacement of corn by sorghum, and the diet containing $85 \mathrm{~g} / \mathrm{kg}$ of ASB increased the colour yolk value, with a mean score of 11.81 . It was also observed that the inclusion of $25 \mathrm{~g} / \mathrm{kg}$ of ASB was enough to obtain a higher yolk colour than that obtained with the diet containing corn. For the level of ASB in the diets containing sorghum, there was a linear increase with the colour score evaluated by the colorimetric range $\left(\mathrm{Y}=6.32+1.4 \mathrm{X} ; \mathrm{R}^{2}=0.98\right)$ with the increased levels of ASB inclusion.

For values of the parameter $\mathrm{L}^{*}$ (lightness), the egg yolks of poultry fed with sorghum with no inclusion of ASB showed a higher value, differing significantly from the results obtained for the other treatments. This parameter did not differ significantly between the yolks of poultry fed with diets containing corn when compared with the diet containing sorghum with the inclusion of $25 \mathrm{~g} / \mathrm{kg}$ of ASB. However, these

Table 4 - Quality of laying hens eggs fed with diets containing sorghum and annatto seed by-product

\begin{tabular}{|c|c|c|c|c|c|c|}
\hline \multirow{2}{*}{ Treatments } & \multicolumn{6}{|c|}{ Parameters $^{1}$} \\
\hline & $\mathrm{HU}$ & $\mathrm{SD}\left(\mathrm{g} / \mathrm{cm}^{3}\right)$ & Albumen $(\%)$ & Yolk (\%) & Eggshell (\%) & $\mathrm{TE}(\mathrm{mm})$ \\
\hline Corn $+0 \mathrm{~g} / \mathrm{kg} \mathrm{ASB}{ }^{2}$ & 87.35 & 1.087 & 66.36 & 24.30 & 9.34 & 0.33 \\
\hline Sorghum $+0 \mathrm{~g} / \mathrm{kg}$ ASB & 86.42 & 1.090 & 66.36 & 24.07 & 9.71 & 0.33 \\
\hline Sorghum $+25 \mathrm{~g} / \mathrm{kg} \mathrm{ASB}$ & 85.17 & 1.091 & 65.82 & 24.51 & 9.57 & 0.34 \\
\hline Sorghum $+45 \mathrm{~g} / \mathrm{kg} \mathrm{ASB}$ & 85.07 & 1.089 & 66.09 & 24.47 & 9.54 & 0.34 \\
\hline Sorghum $+65 \mathrm{~g} / \mathrm{kg}$ ASB & 86.54 & 1.090 & 66.50 & 24.20 & 9.63 & 0.34 \\
\hline Sorghum $+85 \mathrm{~g} / \mathrm{kg} \mathrm{ASB}$ & 85.09 & 1.088 & 66.15 & 24.57 & 9.53 & 0.34 \\
\hline Average & 85.94 & 1.089 & 66.21 & 24.35 & 9.55 & 0.34 \\
\hline $\mathrm{ANOVA}^{3}$ & \multicolumn{6}{|c|}{$P$-value } \\
\hline Treatment & 0.3097 & 0.6105 & 0.2539 & 0.6288 & 0.2034 & 0.6176 \\
\hline Regression Analysis & \multicolumn{6}{|c|}{$P$-value } \\
\hline Linear & 0.7266 & 0.3071 & 0.1556 & 0.9344 & 0.9174 & 0.7815 \\
\hline Quadratic & 0.3973 & 0.8529 & 0.1534 & 0.4247 & 0.7486 & 0.5425 \\
\hline $\mathrm{SEM}^{4}$ & 2.45 & 0.40 & 0.77 & 2.38 & 2.60 & 2.12 \\
\hline
\end{tabular}

${ }^{1} \mathrm{HU}$ - Haugh Unit; SD - Specific Density; TE - Thickness of eggshell; ${ }^{2} \mathrm{ASB}$ - Annatto seed by-product; ${ }^{3} \mathrm{ANOVA}-\mathrm{Analysis}$ of variance $(P>0.05)$ Statistically effect not significant; ${ }^{4} \mathrm{SEM}$ - Standard error of the mean 
Table 5 - Yolk colour of laying hens eggs fed with diets containing sorghum and annatto seed by-product evaluated by two analytical methods

\begin{tabular}{|c|c|c|c|c|}
\hline \multirow{2}{*}{ Treatments } & \multirow{2}{*}{ Colorimetric Range ${ }^{1}$} & \multicolumn{3}{|c|}{ Digital colorimeter $^{2}$} \\
\hline & & $\mathrm{L}$ & $a^{*}$ & $b^{*}$ \\
\hline Corn $+0 \mathrm{~g} / \mathrm{kg} \mathrm{ASB}^{3}$ & $6.28 \mathrm{e}$ & $53.77 \mathrm{~b}$ & $-7.23 \mathrm{e}$ & $35.88 \mathrm{a}$ \\
\hline Sorghum $+0 \mathrm{~g} / \mathrm{kg}$ ASB & $1.26 \mathrm{f}$ & $56.73 \mathrm{a}$ & $-8.64 f$ & $19.69 \mathrm{~d}$ \\
\hline Sorghum $+25 \mathrm{~g} / \mathrm{kg}$ ASB & $7.52 \mathrm{~d}$ & $53.29 b$ & $-5.13 d$ & $32.00 \mathrm{c}$ \\
\hline Sorghum $+45 \mathrm{~g} / \mathrm{kg} \mathrm{ASB}$ & $9.42 \mathrm{c}$ & $51.82 \mathrm{c}$ & $-2.93 \mathrm{c}$ & $34.61 \mathrm{~b}$ \\
\hline Sorghum $+65 \mathrm{~g} / \mathrm{kg}$ ASB & $10.64 \mathrm{~b}$ & $51.22 \mathrm{c}$ & $-1.50 b$ & $36.16 \mathrm{a}$ \\
\hline Sorghum $+85 \mathrm{~g} / \mathrm{kg}$ ASB & $11.81 \mathrm{a}$ & $50.85 \mathrm{c}$ & $-0.14 \mathrm{a}$ & $36.63 \mathrm{a}$ \\
\hline Average & 7.82 & 52.95 & 4.26 & 32.49 \\
\hline $\mathrm{ANOVA}^{4}$ & \multicolumn{4}{|c|}{$P$-value } \\
\hline Treatment & 0.0001 & 0.0001 & 0.0001 & 0.0001 \\
\hline Regression Analysis & \multicolumn{4}{|c|}{$P$-value } \\
\hline Linear & 0.0001 & 0.0001 & 0.0001 & 0.0001 \\
\hline Quadratic & 0.1900 & 0.5730 & 0.1001 & 0.5100 \\
\hline SEM $^{5}$ & 3.27 & 1.93 & 4.63 & 2.44 \\
\hline
\end{tabular}

${ }^{1}$ Roche; ${ }^{2} \mathrm{~L}$ - Lightness, a* - Colour intensity from green to red, $\mathrm{b}^{*}$ - Colour intensity from blue to yellow; ${ }^{3} \mathrm{ASB}-\mathrm{Annatto}$ seed by-product; ${ }^{4} \mathrm{ANOVA}$ - Analysis of variance, average followed by different letters in the column differ by SNK test $(P<0.05)$; ${ }^{5}$ SEM - Standard error of the mean

two treatments provided brightness values significantly higher than those obtained in egg yolks of poultry fed with the inclusion of 45,65 and $85 \mathrm{~g} / \mathrm{kg}$ of ASB in diets containing sorghum. Among the different levels of ASB inclusion, there were linear reductions in the the values of $\mathrm{L}^{*}\left(\mathrm{Y}=53.77-0.79 \mathrm{X} ; \mathrm{R}^{2}=0.91\right)$, with increased of ASB inclusion in the diets containing sorghum.

For parameter values $a^{*}$ (colour intensity from green to red) there was a significant difference between the treatments: the egg yolks of poultry fed with sorghum and inclusion of $85 \mathrm{~g} / \mathrm{kg}$ of ASB showed a higher value of $\mathrm{a}^{*}$, indicating greater intensity of the red colour. The lower intensity of a* was determined for the yolks of poultry fed with sorghum and although this parameter increased with the diet containing corn, the results were nevertheless significantly lower than those obtained with the ASB inclusion from $25 \mathrm{~g} / \mathrm{kg}$ in the diet. There were linear increases for the values of $a^{*}\left(\mathrm{Y}=-6.52+1.64 \mathrm{X} ; \mathrm{R}^{2}=0.98\right)$, with increased in ASB inclusion in the diets containing sorghum.

Evaluating the intensity of the yellow colour (b*) in the egg yolks, the poultry fed with sorghum with no ASB showed a lower value, differing significantly from the results obtained for the other treatments. This parameter did not differ significantly between the egg yolks of poultry fed with diet containing corn or sorghum with ASB inclusion of 65 or $85 \mathrm{~g} / \mathrm{kg}$, however, these treatments resulted in significantly higher $b^{*}$ values than those obtained in egg yolks of poultry fed with the
ASB inclusion of 25 to $45 \mathrm{~g} / \mathrm{kg}$ in diets. Among the ASB treatments, there was a linear increase for values of $b^{*}$ $\left(\mathrm{Y}=+30.99+1.54 \mathrm{X} ; \mathrm{R}^{2}=0.91\right)$ with increased levels of ASB inclusion in diets containing sorghum.

The reduction in the colour of egg yolks with the total replacement of corn by sorghum confirms the reports of previous researchers, since this is the main problem for the use of this grain in the diet (GARCIA et al., 2009; MOURA et al., 2010). However, the effects of the ASB inclusion confirms, in part, the results obtained by other researchers. Silva et al. (2006) evaluated ASB inclusion in diets with $400 \mathrm{~g} / \mathrm{kg}$ of sorghum and noted that although ASB inclusion increased the yolk colour, the maximum inclusion of $120 \mathrm{~g} / \mathrm{kg}$ was not enough to produce yolks similar in colour to that produced by corn-fed hens. Braz et al. (2007) found that the maximum level of $20 \mathrm{~g} / \mathrm{kg}$ of ASB improved the yolk colour, but the values were lower than those obtained with the diets with corn.

The results obtained for lightness $\left(\mathrm{L}^{*}\right)$ suggest that annatto inclusion in laying hen diets promotes an increase in egg yolks coloration by reducing lightness, agreeing with reports by Vera, Custodio and Perales (2015). Garcia et al. (2009) found increases in lightness when sorghum completely replaced corn in the diets, and a reduction of this parameter when the annatto seed was added.

The effects of total replacement of corn by sorghum and ASB inclusion on the intensity of red in egg yolks are similar to those reported by Garcia et al. (2009), 
the inclusion of sorghum reduced the value of $\mathrm{a}^{*}$ at the yolks, letting the colour different of red in the frequency spectrum, while the inclusion of annatto seed increases the values of $\mathrm{a}^{*}$, letting the yolks more reddish.

Based on the above, the effect of ASB inclusion on the values of $\mathrm{a}^{*}$ suggest that ASB used in the study contained bixin, which is a carotenoid red-orange pigment and the main pigment present in annatto seed, responsible for the increased values of $\mathrm{a}^{*}$ in yolks, giving the orange colour.

The effects of the total replacement of corn by sorghum and the annatto seed inclusion on the yellow intensity in the egg yolks are similar to those reported by Garcia et al. (2009). The addition of sorghum reduces the value of $b^{*}$ in the egg yolks, while the addition of annatto seed increases the $b^{*}$ value, letting them more yellow. However, researchers have only obtained $a b^{*}$ intensity similar to that found with corn, when inclusion of annatto seed was $25 \mathrm{~g} / \mathrm{kg}$. However, Silva et al. (2006), reported that though the $b^{*}$ values are linearly increased with the ASB inclusion in the diet containing $40 \%$ of sorghum, the ASB inclusion of $120 \mathrm{~g} / \mathrm{kg}$ did not reach the $\mathrm{b}^{*}$ intensity achieved with a diet containing corn.

The effects of ASB inclusion on the $b^{*}$ values suggest that ASB used in the study contained bixina and norbixin, which are a yellow-red carotenoid pigments. This is can be responsible for the increase in the $b^{*}$ values in the egg yolks of poultry fed diets containing sorghum. In turn, zeaxanthin is the main carotenoid pigment of corn and gives the yellow colour, which explains the higher $b^{*}$ values determined in the egg yolks of poultry fed with diets containing corn as the main energy source.

However, it is important to note that in the annatto seed the proportions of carotenoids bixin and norbixin are variable, and their relationship is dependent on the cultivar. With regard to bixin contents, annatto compounds also suffer great interference from process conditions, being susceptible to decomposition caused by heat, light and oxidation, as well as being potentiated by certain solvents and, once isolated from the seed, bixin becomes very vulnerable to degradation (FRANCO et al., 2013).

Yolk pigmentation, besides the total quantity of pigments, also depends on the proportion of ingested red and yellow carotenoids. This is evident in the results for the colour parameters a* (red) and $b^{*}$ (yellow) between the diets with corn and with ASB. ASB inclusion showed a greater proportion of red colour in yolks, due to their redorange pigments (bixin), while corn showed more yellow colour due to the greater presence of zeaxanthin.

In general, the effects of ASB inclusion on the yolk pigmentation of the are similar to those reported for the addition of annatto seed in diets based on sorghum (GARCIA et al., 2009; LAGANÁ et al., 2011; SPADA et al., 2012).
However, it is important to note that, as occurs for the addition of the whole annatto seed, the magnitude of the egg yolk colour and consequently the variation in results between experiments are related to pigment quantity in the annatto variety, and in the case of residue, to the processing mode for obtaining it (GARCIA et al., 2009). In addition to the fact that the isomerisation of bixin influences, since trans bixin is red in color, differing from the cis isomer, which is more orange in color (SATYANARAYANA et al., 2003).

\section{CONCLUSION}

The results suggest that the annatto seed by-product can be used at levels up to $85 \mathrm{~g} / \mathrm{kg}$ in laying hens diets containing sorghum as the main source of energy. It is thus possible to reduce yolk pigmentation problems with the total substitution of corn by sorghum with the inclusion of ASB from $25 \mathrm{~g} / \mathrm{kg}$, without compromising the diets metabolizable coefficients and metabolizable energy values, the performance of laying hens and the quality of laying hens eggs.

\section{REFERENCES}

ARRAYA, H. H. et al. Composicion y empleo del achiote (Bixa orellana L.) en raciones para gallinas ponedoras, para la pigmentacion de la yema del huevo. Agronomía Costarricense, v. 1, p. 143-150, 1977.

ASSOCIATION OF OFFICIAL ANALYTICAL CHEMISTS. Official methods of analysis of AOAC International. 15th ed. Arlington, Virginia, USA, 1995.

BOLOGNESI, V. J.; GARCIA, C. E. R. Annatto carotenoids as additives replacers in meat products. In: GRUMEZESCU, A.; HOLBAN, A. M. Alternative and replacement foods. London: Elsevier Science, 2018. v. 17, cap. 12, p. 355-384.

BRAZ, N. M. et al. Semente residual do urucum na alimentação de poedeiras comerciais: desempenho e características dos ovos. Acta Scientiarum Animal Sciences, v. 29, p. 129-133, 2007.

FAGUNDES, N. S. et al. Replacing corn with sorghum in the diet alters intestinal microbiota without altering chicken performance. Journal of Animal Physiology and Animal Nutrition, v. 101, p. 371-382, 2017.

FRANCO, C. F. O. et al. Quebra de dormência e influência nos teores de bixina em sementes de urucum submetidas à radiação gama. Tecnologia \& Ciência Agropecuaria, v. 7, p. 13-18, 2013.

FREITAS, E. R. et al. Comparação de métodos de determinação da gravidade específica de ovos e poedeiras comerciais. Pesquisa Agropecuária Brasileira, v. 39, p. 509-512, 2004.

FREITAS, E. R. et al. Substituição do farelo de soja pelo farelo de coco em rações contendo farelo da castanha de caju para frangos de corte. Revista Brasileira de Zootecnia, v. 40, p. 1006-1013, 2011. 
GARCIA, E. A. et al. Desempenho e qualidade dos ovos de poedeiras comerciais alimentadas com semente de Urucum (Bixa orellana L.) moída na dieta. Arquivo Brasileiro de Medicina Veterinária e Zootecnia, v. 16, p. 689-697, 2009.

GARCIA, E. A. et al. Ground annatto seeds (bixa orellana 1.) in sorghum-based commercial layer diets and their effects on performance, egg quality, and yolk pigmentation. Brazilian Journal of Poultry Science, v. 12, p. 259-264, 2010.

GARCIA, R. G. et al. Desempenho e qualidade dos ovos de poedeiras alimentadas com semente de urucum. Arquivos de Ciências Veterinárias e Zoologia da UNIPAR, v. 18, p. 17-20, 2015.

KUFEL, L. G. S. et al. Performance and egg quality of Japanese quails fed ground sorghum diets and increasing levels of Brazilian ginseng (Pfaffia paniculata). Livestock Science, v. 227, p. 17-21, 2019.

LAGANÁ, C. et al. Turmeric root and annato seed in secondcycle layer diets: performance and egg quality. Brazilian Journal of Poultry Science, v. 13, p. 171-176, 2011.

MATTERSON, L. D. et al. The metabolizable energy of feeds ingredient for chickens. Agricultural Experiment Station Research Report, n. 7, p. 3-11, 1965.

MOLNÁR, A. et al. Sequential and choice feeding in laying hens: adapting nutrient supply to requirements during the egg formation cycle. World's Poultry Science Journal, v. 74, p. 199-210, 2018.

MORAES, C. A. et al. Performance and meat chemical composition of quails fed with different sorghum levels instead of corn. Ciência Rural, v. 46, p. 933-936, 2016.

MOURA, A. M. A. et al. Desempenho e qualidade do ovo de codornas japonesas alimentadas com rações contendo sorgo. Revista Brasileira de Zootecnia, v. 39, p. 2697-2702, 2010.

NATIONAL RESEARCH COUNCIL. Nutrient requirements of poultry. 9th ed. Washington, D.C., USA, 1994.

RADDATZ-MOTA, D. et al. Achiote (Bixa orellana L.): a natural source of pigment and vitamin E. Journal of Food Science and Technology, v. 54, p. 1729-1741, 2017.

SALEH, A. A. et al. The effects of replacing corn with lowtannin sorghum in broiler's diet on growth performance, nutrient digestibilities, lipid peroxidation and gene expressions related to growth and antioxidative properties. Journal of Applied Animal Research, v. 47, p. 532-539, 2019.

SATYANARAYANA, A. et al. Chemistry, processing and toxicology of annatto (Bixa orellana L.). Journal of Food Science Technology, v. 40, p. 131-141, 2003.

SIBBALD, I. R.; SLINGER, S. J. A biological assay for metabolizable energy in feed ingredients together with finding wich demonstrate some of the problems associated with the evaluation of fats. Poultry Science, v. 42, p. 313-325, 1963.

SILVA, J. H. V. et al. Efeitos da inclusão do resíduo da semente de urucum (Bixa orellana L.) na dieta para de frangos de corte: desempenho e características de carcaça. Revista Brasileira de Zootecnia, v. 34, p. 1606-1613, 2005.

SILVA, J. H. V. et al. Resíduo da semente de urucum (bixa orellana) como corante da gema, pele, bico e ovário de poedeiras avaliado por dois métodos analíticos. Ciência e Agrotecnologia, v. 30, p. 988-994, 2006.

SOUZA, D. H. et al. Inclusion of annatto seed by-product in diets containing sorghum for slow-growth broilers. Ciência e Agrotecnologia, v. 39, p. 248-259, 2015.

SOUZA, L. A. Z. et al. Egg yolk colour and retinol concentration of eggs from laying hens fed diets containing carrot and beetroot meal. Czech Journal of Animal Science, v. 64 , p. 395-403, 2019.

SPADA, F. P. et al. Adição de carotenóides naturais e artificiais na alimentação de galinhas poedeiras: efeitos na qualidade de ovos frescos e armazenados. Ciência Rural, v. 42, p. 346-353, 2012.

UL-ISLAM, S.; RATHER, L. J.; MOHAMMAD, F. Phytochemistry, biological activities and potential of annatto in natural colourant production for industrial applications: a review. Journal of Advanced Research, v. 7, p. 499-514, 2015.

VERA, V. R.; CUSTODIO, M. C.; PERALES, V. A. Uso de un aditivo a base de cantaxantina y extracto de achiote en dietas de gallinas de postura y su efecto sobre la coloración de la yema y la vida de anaquel del huevo. Science in Agrochemicals, v. 6, p. 191-199, 2015. 